\title{
EFFECTS OF ALTITUDE ON SEEDS GERMINATION AND LUMINOSITY LEVELS ON THE VEGETATIVE DEVELOPMENT OF Schinus terebinthifolius Raddi
}

\author{
Norma Barbado ${ }^{1 *}$, Marcelo Bevilacqua Remor ${ }^{2}$, Patrícia Pereira Gomes ${ }^{3}$, Fernanda Rúbio ${ }^{4}$, Rodrigo de Oliveira ${ }^{5}$, \\ Élcio Silvério Klosowski ${ }^{7}$ \\ 1*Instituto Federal do Paraná, Programa de Mestrado em Sustentabilidade (PSU), Umuarama, Paraná, Brasil - norma.barbado@ifpr.edu.br \\ ${ }^{2}$ Universidade Estadual do Oeste do Paraná, Centro de Ciências Exatas e Tecnológicas (CCET), Cascavel, Paraná, Brasil - \\ remor_@hotmail.com \\ ${ }_{3}^{3}$ Instituto Federal do Paraná, Programa de Mestrado em Sustentabilidade (PSU), Umuarama, Paraná, Brasil - patricia.gomes @ifpr.edu.br \\ ${ }^{4}$ Instituto Federal do Paraná, Biologia, Foz do Iguaçu, Paraná, Brasil - fernanda.rubio@ifpr.edu.br \\ ${ }^{5}$ Instituto Federal do Paraná, Matemática, Umuarama, Paraná, Brasil - rodrigo.oliveira@ifpr.edu.br \\ ${ }^{6}$ Universidade Estadual do Oeste do Paraná, Programa de pós-graduação em Agronomia (PPGA), Marechal Cândido Rondon, Paraná, Brasil \\ - elciork1@yahoo.com.br
}

Received for publication: 29/04/2020 - Accepted for publication: 04/09/2020

\begin{abstract}
Resumo
Influência da altitude na germinação de sementes e níveis de luminosidade no desenvolvimento vegetativo de Schinus terebinthifolius Raddi. A Schinus terebinthifolius é uma espécie pioneira importante da Mata Atlântica. Assim, o objetivo foi avaliar o processo de germinação de sementes de S. terebinthifolius coletadas em quatro locais com diferentes altitudes (São Francisco do Sul/SC, 2,53 m; Foz do Iguaçu/PR, 176,67 m; Maringá/PR, $458,00 \mathrm{~m}$; Guarapuava/PR, 1.048,70 m) e seu desenvolvimento inicial sob quatro níveis de luminosidade. No teste de germinação, o delineamento experimental foi inteiramente casualizado, com 12 repetições de 50 sementes por tratamento. As mudas foram submetidas aos níveis de luminosidade de 50, 60, 70 e $100 \%$. Os fatores: local de coleta das sementes, luminosidade e tempo de desenvolvimento das mudas, foram avaliados por esquema fatorial triplo, com quatro níveis em cada fator $\left(4^{3}\right)$. A análise dos componentes principais foi aplicada sobre a matriz de correlação no conjunto das variáveis respostas provenientes dos tratamentos. Sementes coletadas em São Francisco do Sul/SC apresentaram maior vigor e índice de velocidade de germinação (IVG), desempenho superior no comprimento da raiz primária e da parte aérea. Porém, estas apresentaram o pior resultado no desenvolvimento vegetativo das mudas submetidas a $50 \%$ de luminosidade. Sementes coletadas em Maringá/PR apresentaram a menor porcentagem de germinação e IVG, porém obtiveram os melhores resultados no desenvolvimento vegetativo das mudas, quando submetidas a $70 \%$ de luminosidade. Este estudo confirmou que mudas de $S$. terebinthifolius, quando expostas a luminosidade acima de $60 \%$, apresentam melhor adaptação e desenvolvimento, porém novos estudos sobre altitude e manejo devem ser realizados, propiciando a recuperação de áreas degradadas.

Palavras-chave: pimenta rosa; Mata Atlântica; reflorestamento.
\end{abstract}

\begin{abstract}
Schinus terebinthifolius is a pioneer species of the Atlantic Forest. Thus, this study aims to evaluate the germination process of $S$. terebinthifolius seeds collected in four sites with different altitudes (São Francisco do Sul/SC, 2.53 m; Foz do Iguaçu/PR, 176.67 m; Maringá/PR, 458.00 m; Guarapuava/PR, 1,048.70 m) and their initial development under four luminosity levels. For the germination test, we used the completely randomized experimental design with 12 repetitions with 50 seeds per treatment. The seedlings were subjected to the luminosity levels of 50,60, 70, and $100 \%$. A triple factorial scheme, with four levels in each factor $\left(4^{3}\right)$ was used to evaluate the seed collection site, luminosity, and seedling's development period. Principal components analysis was applied to the correlation matrix in the set of response variables emerging from the treatments. Seeds collected in São Francisco do Sul/SC presented higher vigor, and better germination speed index (GSI), development of the primary root and aerial part length. However, they also presented the worst result for the vegetative growth of seedlings subjected to a luminosity of $50 \%$. Seeds collected in Maringá/PR presented a lower germination percentage and GSI. Still, they obtained the better results for vegetative development of seedlings subjected to a luminosity of $70 \%$. This study confirmed that S. terebinthifolius seedlings, when exposed to luminosity higher than $60 \%$, present better adaptation and development. Nonetheless, further studies about altitude and management are required to foster the recovery of degraded areas.
\end{abstract}

Keywords: Rose pepper; Atlantic Forest; Reforestation.

\section{INTRODUCTION}

The Atlantic Forest degradation in Brazil is unrestrained, which reduces drastically this forest's biodiversity (NASSER et al., 2019). Among Atlantic Forest pioneer species, Schinus terebinthifolius Raddi (S. terebinthifolius), popularly known as Brazilian peppertree or rose pepper (NEVES et al., 2016), stands out by its use to recover degraded areas and its fast development (SOUZA et al., 2013). Its fruits are ovoid drupes between 
4 and $5 \mathrm{~mm}$, which, when mature, present a reddish color and a sweet and aromatic taste (NEVES et al., 2016). Such characteristic favors the intense circulation of animals, mainly birds seeking food, which consequently promotes seed dispersal.

The seeds of S. terebinthifolius also have an important commercial prospect by presenting medicinal, phytochemical, and nutritional properties (SILVA et al., 2017). Nevertheless, there are few studies that evaluate their physiological quality (SHIBATA et al., 2019).

Due to the ecological unbalance of the Atlantic Forest, the adoption of seed germination practices and seedlings production techniques is needed to propagate and conserve native species and the forest's biodiversity (NASSER et al., 2019). Thus, it is fundamental to the know the mechanisms involved in seed germination, especially those associated with light quality and temperature (RAMOS et al., 2020). Seed germination regarding light exposition is an ecophysiological response of the species, which may be related to its position in the successional stage of the forest (MAEKAWA et al., 2010). Besides, altitude is another parameter that may influence plants' propagation. Nevertheless, studies about seed germination and the production of Atlantic Forest native species' seedlings from seeds collected in different altitudes are still scarce in Brazil (SOUZA et al., 2013).

Therefore, it is fundamental to evaluate if the parameters altitude and luminosity levels influence seeds germination and seedling production in order to determine the best practices (SOUZA et al., 2013), providing new data to forest science. Thus, this study aims to evaluate the germination of $S$. terebinthifolius seeds collected in four sites with different altitudes and the initial development of seedlings under four luminosity levels.

\section{MATERIALS AND METHODS}

The fruits of S. terebinthifolius were collected from a total of 12 mother plants of four different Brazilian cities with different altitudes (Figure 1): São Francisco do Sul/SC (S1), in the Parque Estadual Acaraí; Foz do Iguaçu/PR (S2), in the Refúgio Biológico Bela Vista de Itaipu; Maringá/PR (S3), in an urban area; Guarapuava/PR (S4), in the Parque Municipal das Araucárias.

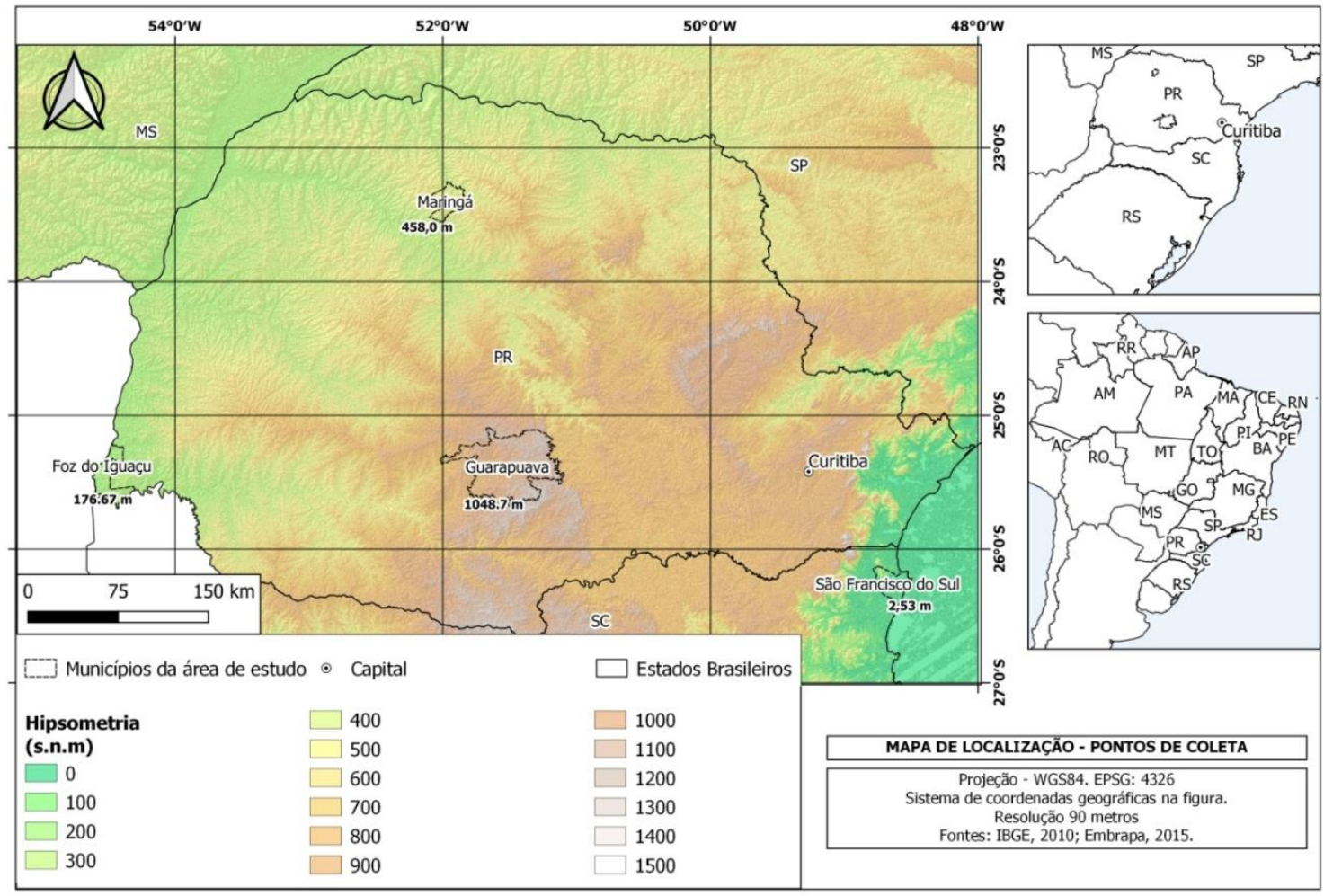

Figure 1. Collection sites of $S$. terenbinthifolius seeds and their respective altitudes.

Figura 1. Locais de coleta de sementes de S. terenbinthifolius e suas respectivas altitudes.

Source. Embrapa (2015); IBGE (2010).

The collection occurred in the second reproductive period of the plant in April 2013. The predominant biome of the collection sites was the Atlantic Forest. The average annual temperature, precipitation, altitude, climate, and soil are described in Table 1. 
Table 1. Characteristics of the collection sites of S. terenbinthifolius fruits: São Francisco do Sul/SC (S1), Foz do Iguaçu/PR (S2), Maringá/PR (S3), and Guarapuava/PR (S4).

Tabela 1. Características relacionadas aos locais de coleta de frutos de S. terenbinthifolius: São Francisco do Sul/SC (S1), Foz do Iguaçu/PR (S2), Maringá/PR (S3) e Guarapuava/PR (S4).

\begin{tabular}{lcccc}
\hline & S1 & S2 & S3 & S4 \\
\hline Annual AT $\left({ }^{\circ} \mathrm{C}\right)$ & $* 21.2$ & $* 21.6$ & $* 17.7$ & $* 16.7$ \\
Annual AP $(\mathrm{mm})$ & $* 1,830$ & $* * 176.67$ & $* * 458.00$ & $* 1,711$ \\
AA $(\mathrm{m})$ & $* * 2.533$ & $* \mathrm{Cfa}$ & $* \mathrm{Cfb}$ & $* * 1,048.70$ \\
Climate $($ Köppen $)$ & $* \mathrm{Cfa}$ & $* * *$ LVdf4 & $* * * \mathrm{NVe} 2$ & $* \mathrm{Cfb}$ \\
Soil type & $* * *$ ESKo & (Av 226 & $* *$ LBd1
\end{tabular}

Legend: average temperature (AT), average precipitation (AP), average altitude (AA), Espodossolo Ferrihumilívico Órtico + Neossolo Quartizênico Órtico (ESKo), Latossolo Vermelho Distroférrico + Nitossolo Vermelho Eutroférrico (LVdf4), Nitossolo Vermelho Eutrófico + Latossolo Vermelho Eutroférrico (NVe2), Latossolo Bruno Distrófico (LBd1).

Source. *Alvares et al, 2013; **means measured by the authors based on GPS data found in collection sites; ***SiBCS, 2018.

Three S. terenbinthifolius specimens of each site were collected, which presented fruits with mature pericarp, with a minimum distance of $100 \mathrm{~m}$ between the plants. Each tree was georeferenced and evaluated according to the main dendrometric variables (Table 2): height $(\mathrm{H})$, crown projection area (CPA), diameter at chest height (DCH), and point of morphological inversion (PMI).

Table 2. Characteristics of the S. terebinthifolius specimens of São Francisco do Sul/SC (S1), Foz do Iguaçu/PR (S2), Maringá/PR (S3), and Guarapuava/PR (S4) used in this study.

Tabela 2. Características dos exemplares de S. terebinthifolius de São Francisco do Sul/SC (S1), Foz do Iguaçu/PR (S2), Maringá/PR (S3) e Guarapuava/PR (S4) utilizadas neste estudo.

\begin{tabular}{clccccccc}
\hline & & Average & CV \% & SD & Variance & Minimum & Average & Maximum \\
\hline S1 & H (m) & 4.40 & 15.75 & 0.693 & 0.480 & 4.000 & 4.000 & 5.200 \\
& CPA (m $\left.{ }^{2}\right)$ & 24.02 & 70.78 & 17.00 & 289.04 & 11.26 & 17.48 & 43.32 \\
& DCH (m) & 0.18 & 96.86 & 0.174 & 0.030 & 0.060 & 0.100 & 0.380 \\
& PMI (m) & 0.63 & 82.49 & 0.520 & 0.270 & 0.320 & 0.340 & 1.230 \\
\hline S2 & H (m) & 3.98 & 24.61 & 0.980 & 0.961 & 2.950 & 4.100 & 4.900 \\
& CPA (m $\left.{ }^{2}\right)$ & 32.00 & 58.71 & 18.8 & 353.6 & 17.6 & 25.2 & 53.3 \\
& DCH (m) & 0.07 & 20.83 & 0.01528 & 0.00023 & 0.06000 & 0.07000 & 0.09000 \\
& PMI (m) & 0.44 & 147.85 & 0.655 & 0.430 & 0.050 & 0.080 & 1.200 \\
\hline S3 & H (m) & 8.33 & 6.93 & 0.577 & 0.333 & 8.000 & 8.000 & 9.000 \\
& CPA (m $\left.{ }^{2}\right)$ & 29.8 & 21.78 & 6.49 & 42.12 & 24.40 & 28.00 & 37.00 \\
& DCH (m) & 0.17 & 30.20 & 0.0503 & 0.0025 & 0.1200 & 0.1600 & 0.2200 \\
& PMI (m) & 0.33 & 61.88 & 0.204 & 0.042 & 0.100 & 0.400 & 0.490 \\
\hline S4 & H (m) & 8.67 & 29.04 & 2.52 & 6.33 & 6.00 & 9.00 & 11.00 \\
& CPA (m $\left.{ }^{2}\right)$ & 6.72 & 16.50 & 1.109 & 1.229 & 5.700 & 6.560 & 7.900 \\
& DCH (m) & 0.16 & 12.50 & 0.0200 & 0.0004 & 0.1400 & 0.1600 & 0.1800 \\
& PMI (m) & 0.55 & 23.31 & 0.1274 & 0.0162 & 0.4000 & 0.6100 & 0.6300
\end{tabular}

Legend: coefficient of variation (CV \%), standard deviation (SD), average height of mother plants (H), average crown projection area (CPA), average diameter at chest height $(\mathrm{DCH})$, average point of morphological inversion (PMI).

Fruits were collected in situ, conditioned in paper bags and sent to the Refúgio Biológico Bela Vista de Itaipu in the city of Foz do Iguaçu/PR, Brazil, where they were stored in a refrigerator at $4{ }^{\circ} \mathrm{C}$. The fruits were processed in May 2013. The structures used were the fruits without exocarp, here treated as seeds. Fruit's exocarp extraction was conducted manually, using a sieve and running water. We also used sieves to uniformize seeds' size for the experiment (processing).

\section{Germination of $S$. terebinthifolius}

Thousand seeds of $S$. terebinthifolius were characterized regarding average diameter (AD), fresh mass (FM), and dry mass (DM) based on four repetitions for each mother plant. Samples were measured with an analytical balance (precision of $0.001 \mathrm{~g}$ ) before and after the drying period in a stove at $105 \pm 3{ }^{\circ} \mathrm{C}$ for 24 hours (BRASIL, 2009). 
The germination test was conducted in a germination chamber MA 402 with a programmed temperature variation: $30{ }^{\circ} \mathrm{C}$ bright period (16 hours), and $25{ }^{\circ} \mathrm{C}$ dark period $(8 \mathrm{~h})$ following previous experiences of the biologist and other employees (parataxonomists) of the Refúgio Biológico Bela Vista with the germination of different forest plant species (RUBIK, 2011, Unpublished data). The seeds were conditioned in plastic germination boxes containing a two centimeters layer of vermiculite as a substrate, moistened with distilled water equivalent to 2.0 times its dry mass (BRASIL, 2009). We used a completely randomized design (CRD) with twelve repetitions of 50 seeds per treatment (on the collection site), totaling 600 seeds per treatment.

The first seed counting occurred seven days after seeding. Then, there were counts 14 and 21 days after seeding. Seeds that presented developed radicle and visually normal plumule were considered germinated (MEDEIROS; ZANON, 1998). In all observations, the number of germinated seeds and the amount of normal and anormal seedlings were registered; the results were expressed as germination percentage (BRASIL, 2009). Germination speed was determined during the experimental period through weekly evaluations. The germination speed index (GSI) was measured through an adaptation of Maguire's Equation (1962), as expressed in Equation 1.

$$
\mathrm{GSI}=\frac{\mathrm{G}_{1}}{\mathrm{~N}_{1}}+\frac{\mathrm{G}_{2}}{\mathrm{~N}_{2}}+\frac{\mathrm{G}_{3}}{\mathrm{~N}_{3}}
$$

where: G1, G2, and G3 = number of normal seedlings registered in the first, second, and third counts, N1, N2, and $\mathrm{N} 3$ = number of days between the seeding and the first, second, and third counts.

After 21 days of observation, normal seedlings were separated by measuring the roots and the aerial part with a graded caliper. The diameter of the root crown was measured with a 798 series digital caliper. The data obtained were subjected to the normality test of residual distribution. Results related to germination percentage were subjected to the analysis of variance (ANOVA) and the means compared through Tukey's test with $\mathrm{p}<0.05$. To test the percentage means of non-germinated seed (NGS), normal seedlings (NS), and anormal seedlings (AS), the Mann-Whitney method with $\mathrm{p}<0.05$ was used because the data did not present normality. The analyses were conducted with the Assistat software version 7.7 beta.

\section{Vegetative development of S. terebinthifolius under four luminosity levels}

Seedlings production and their morphophysiological analyses were conducted between May and September 2013. Seeds of S. terebinthifolius collected in S1, S2, S3, and S4 were put on a nursery inside the green house of the Refúgio Biológico Bela Vista de Itaipu. The substrate was a two centimeters layer of vermiculite, following the methodology of the Brazilian seed analysis norms (BRASIL, 2009). Germination and seedling development were observed for 15 days, divided in three phases (emergence, seedling, and young plant). Transplanting was conducted 15 days after seeding ( 3 rd phase, young plant). The seedlings were transplanted to plane trays of $60 \mathrm{~cm}$, each one containing 108 units of polypropylene tubes $\left(116 \mathrm{~cm}^{3}\right)$ MEC PREC. The commercial substrate used consists of $80 \%$ pine bark and $20 \%$ humus, with the addition of slow release NPK (185-9) and the following chemical characteristics: $\mathrm{pH}: 6.6$; P: 189; K: 470; Na: 20; Ca: 13.1; $\mathrm{Mg}: 13.9 ; \mathrm{Al}: 0$; $\mathrm{H}+$ Al: 7.0; cation exchange capacity: 35.27 ; sum of bases: 28.28 ; saturation per basis: 80 ; saturation per aluminum: 0 ; electrical conductivity: 0.94 ; total content of soluble salts: 3.17 .

The trays were stored in a hanging metal nursery, with the size $1.20 \times 5.00 \mathrm{~m}$, organized in four different environments: $50 \%$ luminosity (L1), $60 \%$ luminosity (L2), $70 \%$ luminosity (L3), and full sunlight with $100 \%$ luminosity (L4). Thus, there were 16 treatments with 9 repetitions each (9 trays with 108 tubes, and a total of 972 seedlings per treatment). The three first environments had a shade cloth cover with the respective sun rates: 50 , 40, and 30\%. A micro-sprinkler liberating $93 \mathrm{~L}$ of water per hour irrigated the area four times a day per ten minutes during summer, which was reduced by approximately $50 \%$ during winter due to the necessity observed.

Analyses regarding seedlings growth and physiology occurred in the collections at 30, 60, 90, and 120 days after transplanting. The following growth rates were evaluated: plant height (PH), crown diameter (CD), root length (RL), root fresh mass (RFM), root dry mass (RDM), stem + petiole fresh mass (SFM), stem + petiole dry mass (SDM), leaves fresh mass (LFM), leaves dry mass (MSF), total fresh mass (TFM), and total dry mass (TDM).

A digital caliper was used to measure $\mathrm{CD}$, and a millimeter scale to measure PH and RL. To evaluate RFM, RDM, SFM, SDM, LFM, TFM, and TDM, three seedlings of each treatment with uniform growth during the experiment were selected. The seedlings had their clods removed, were cleaned and separated into three parts: root, stem + petiole, and leaflets. Then, the mass was measured with a precision balance $(0.01 \mathrm{~g})$, and the material was stored in a stove at $70{ }^{\circ} \mathrm{C}$ until obtaining the constant weight $(24 \mathrm{~h})$ for a new mass measurement. The experiment design was organized in a triple factorial scheme with four levels in each factor $\left(4^{3}\right)$. The factors evaluated were altitude of the seeds collection site, seedlings' luminosity level, and period of cultivation (30, 60, 90, and 120 days after seeding) with nine repetitions (9 trays with 108 tubes each). The two higher and lower 
values for each factor were neglected. Therefore, only five repetitions for each evaluation were considered for the statistical analyses.

In each response variable studied for each treatment, a model of simple linear regression was generated between the period and the response variable of the treatment (seed collection site and luminosity), and the intercept passed by the origin. Thus, the linear model of Equation 2 was used.

$$
y=b_{1} \times \mathrm{t}
$$

where: $\mathrm{b} 1$ = growth or increment rate (depending on the variable) for each treatment during the experimental period, $\mathrm{t}=$ time.

Through the analysis of variance (ANOVA), an equality was verified between the simple linear models. The values of the growth or increment rates presented normal distribution according to Shapiro-Wilk's test and homoscedasticity according to Bartlett's test, both with $\mathrm{p}<0.05$. The analyses of the biometric response variables (PH, CD, RL, RFM, RDM, SFM, SDM, LFM, LDM, TFM, and TDM) were evaluated by the multivariate analysis (MANOVA) with $\mathrm{p}<0.05$ to verify if the data were randomly generated and not due to the treatments. For the significant response variables, univariate analysis of variance (ANOVA) and Tukey's test were conducted, both with $\mathrm{p}<0.05$.

Principal components analysis (PCA) was applied to identify the better treatment to produce $S$. terebinthifolius seedlings in the set of response variables (b1) provided by the treatments, using the software PCORD 4.0 (McCUNE; MEFFORD, 1999). PCA was performed on the Pearson correlation matrix of the variables, and the retention criterium of the principal components (PCs) adopted was the "broken-stick", i.e., with higher eigenvalues than what randomly expected (JACKSON, 1993). The randomization test with 999 interactions was also used to verify if the variance in the axis PC is caused by the treatments or randomly. To interpret the significance of the PCs retained from the original variables, only the Pearson correlation coefficients higher than $70 \%$ were considered (JOLLIFFE, 2002).

\section{RESULTS}

\section{Germination of $S$. terebinthifolius}

The samples of $S$. terebinthifolius seeds selected for this study were characterized regarding their average diameter. The seeds collected in São Francisco do Sul/SC (S1), the site with lower altitude, presented higher results than the others with statistical differences between the treatments (Table 3). The same occurred regarding fresh mass. However, the results for dry mass did not differ statistically (Table 3).

Table 3. Average diameter (AD), fresh mass (FM), and dry mass (DM) by thousand seeds of S. terebinthifolius from four different sites: São Francisco do Sul/SC (S1), Foz do Iguaçu/PR (S2), Maringá/PR (S3), and Guarapuava/PR (S4).

Tabela 3. Diâmetro médio (DM), massa fresca (MF) e massa seca (MS) de mil sementes de S. terebinthifolius provenientes de quatro locais diferentes: São Francisco do Sul/SC (S1), Foz do Iguaçu/PR (S2), Maringá/PR (S3) e Guarapuava/PR (S4).

\begin{tabular}{lcccccccc}
\hline & S1 & CV\% & S2 & CV\% & S3 & CV\% & S4 & CV\% \\
\hline $\mathrm{AD}(\mathrm{mm})$ & $5.50 \pm 0.103 \mathrm{a}$ & 6.23 & $4.17 \pm 0.105 \mathrm{c}$ & 0.98 & $4.50 \pm 0.103 \mathrm{~b}$ & 4.59 & $4.66 \pm 0.103 \mathrm{~b}$ & 1.93 \\
$\mathrm{FM}(\mathrm{g})$ & $22.69 \pm 0.569 \mathrm{a}$ & 7.1 & $20.07 \pm 0.569 \mathrm{c}$ & 2.43 & $21.42 \pm 0.566 \mathrm{~b}$ & 1.81 & $20.98 \pm 0.570 \mathrm{bc}$ & 7.08 \\
$\mathrm{DM}(\mathrm{g})$ & $13.195 \pm 0.634 \mathrm{a}$ & 11.58 & $12.87 \pm 0.634 \mathrm{a}$ & 10.06 & $12.89 \pm 0.634 \mathrm{a}$ & 6.04 & $12.48 \pm 0.634 \mathrm{a}$ & 10.76 \\
\hline
\end{tabular}

Means followed by the same letter in the line do not differ statistically from each other by the Tukey's test at $5 \%$.

Regarding the percentage of S. terebinthifolius seeds germinated in the first count, the seeds collected in S1 also presented better results. The other treatments presented similar results between them (Table 4). For the parameter germination speed index (GSI), S1 presented better results than the others (Table 4).

Table 4. Germinated seeds and germination speed index of S. terebinthifolius from four different sites: São Francisco do Sul/SC (S1), Foz do Iguaçu/PR (S2), Maringá/PR (S3), and Guarapuava/PR (S4).

Tabela 4. Sementes germinadas e índice de velocidade de germinação (IVG) de S. terebinthifolius provenientes de quatro locais diferentes: São Francisco do Sul/SC (S1), Foz do Iguaçu/PR (S2), Maringá/PR (S3) e Guarapuava/PR (S4).

\begin{tabular}{lcccc}
\hline & S1 & S2 & S3 & S4 \\
\hline Germinated Seeds (\%) & 55,67 & 28,83 & 23,33 & 25,17 \\
GSI & 8,33 & 4,54 & 3,70 & 3,56 \\
\hline
\end{tabular}


In table 5, it is possible to verify the results of the evaluations regarding the variables: normal seedlings (NS), non-germinated seeds (NGS), and anormal seedlings (AS), as well as the evaluations regarding root length (RL), aerial part length (APL), and crown diameter (CD). The results demonstrate that S1 seeds outperform the others significantly regarding NS and present lower percentage of NGS, differing significantly from the samples of S2, S3, and S4 (Table 5). The lower amount of AS was obtained from seeds collected in S4 (Table 5). The samples of S3 presented higher amount of anormal plants. Still, they did not differ significantly compared with the results of $\mathrm{S} 1$ and $\mathrm{S} 2$ (Table 5).

Table 5. Results of the germination tests for S. terebinthifolius regarding seeds collected in four different sites 21 days after seeding.

Tabela 5. Resultados dos testes de germinação de S. terebinthifolius a partir de sementes coletadas em quatro locais diferentes aos 21 dias após a semeadura.

\begin{tabular}{|c|c|c|c|c|c|}
\hline & S1 & S2 & S3 & S4 & $\mathbf{H}$ \\
\hline NGS (\%) & $23 \mathrm{~b}$ & $57 \mathrm{a}$ & $66 \mathrm{a}$ & $70 \mathrm{a}$ & $27.34 * *$ \\
\hline NS (\%) & $70 \mathrm{a}$ & $30 \mathrm{~b}$ & $19 \mathrm{~b}$ & $26 \mathrm{~b}$ & $27.85^{* *}$ \\
\hline $\mathrm{AS}(\%)$ & $7 \mathrm{ab}$ & $13 \mathrm{a}$ & $15 \mathrm{a}$ & $4 \mathrm{~b}$ & $13.77 * *$ \\
\hline $\mathrm{RL}(\mathrm{cm})$ & $2.958 \mathrm{a}$ & $2.146 \mathrm{~b}$ & $2.817 \mathrm{a}$ & $2.250 \mathrm{ab}$ & $8.29 * *$ \\
\hline APL $(\mathrm{cm})$ & $4.673 \mathrm{a}$ & $4.292 \mathrm{a}$ & $3.208 \mathrm{~b}$ & $2.917 \mathrm{~b}$ & $21.90 * * *$ \\
\hline $\mathrm{CD}(\mathrm{mm})$ & $0.529 \mathrm{~b}$ & $0.575 \mathrm{ab}$ & $0.642 \mathrm{a}$ & $0.400 \mathrm{~b}$ & $11.51 * * *$ \\
\hline
\end{tabular}

Legend: germination speed index (GSI), normal seedlings (NS), anormal seedlings (AS), root length (RL), aerial part length (APL), crown diameter $(\mathrm{CD})$.

*Means followed by the same letter in the line do not differ from each other by the Tukey's test at $5 \%$.

*** Means followed by the same letter in the line do not differ from each other by the Mann-Whitney test at $1 \%$.

******Means followed by the same letter in the line do not differ from each other by the Kruskal-Wallis test at $1 \%$.

The seedlings produced by the seeds obtained in S1, S2, S3, and S4 presented the following characteristics: low value for RL in S2; longer roots in S1, without significant difference for S3 and S4; higher APL in S1 and S3; higher means for CD in S3, without statistical difference from S2; lower CD in S4 (Table 5). Concerning these results, $S$. terebinthifolius seeds collected in S1 (site with lower altitude), in the same reproductive cycle of those collected in $\mathrm{S} 2, \mathrm{~S} 3$, and $\mathrm{S} 4$, were more viable.

\section{Vegetative development of $S$. terebinthifolius under different luminosity levels}

The emergence of $S$. terebinthifolius in the nursery started two days after seeding and finished after eight days, presenting a phanerocotylar epigeal germination. The first phase of development presented cotyledons attached to the apex, which tended to open. Also, in this stage, the radicle presented hairs, and then the cotyledons became free, small, with traces of secondary roots. The second stage, called seedling, presented the emergence of protophylls. In this stage, a thin root, sometimes sinuous, emerged with pale hairs and few secondary roots. Besides, the flat root crown was cylindric, the limb had three nervures sometimes reddish in the abaxial surface. The seedlings were transplanted in the third phase, 15 days after seeding, with axial roots slightly tuberous, and secondary roots still underdeveloped and sparse. In this phase, the hypocotyl was thicker in the base with straight or reticular stria. Besides, the cotyledons disappeared, remaining only a scar. The epicotyl observed was straight, with straight or reticular stria. The first two protophylls observed were opposite and trifoliolate, and the remaining petiolated, imparipinnate, with five to seven leaflets in an alternated fashion. The protophyll presented small grooves on the adaxial surface. The leaflets were opposite, short, and petiolated. The stem presented some hairs and stria on the base and was thicker on the apex than the base. The lenticels were numerous between the stria.

The results obtained 30,60, 90, and 120 days after transplanting S. terebinthifolius seedlings subjected to different luminosity levels were significant at a probability of error of $5 \%$. The principal components analysis resulted in 6 PCs of significant linear combinations. However, according to the Broken-stick criterium, only PC1 had an explanation percentage of $63,94 \%$ with $\mathrm{p}<0.05$. By using the Pearson correlation test between the principal components and the variables, only the variable root length (RL) presented low influence for PC1.

S. terebinthifolius seedlings that presented better results for vegetative growth were produced with seeds collected in S3 (average altitude of $458 \mathrm{~m}$ ), when subjected to $70 \%$ luminosity (L3). The seedlings presented lower variability (Figure 2) and favorable conditions to plants' establishment. It is worth mentioning that in the germination test seeds from S3 had the higher percentage of anormal seedlings. However, the normal seedlings presented the higher crown diameter and a significant root length. 


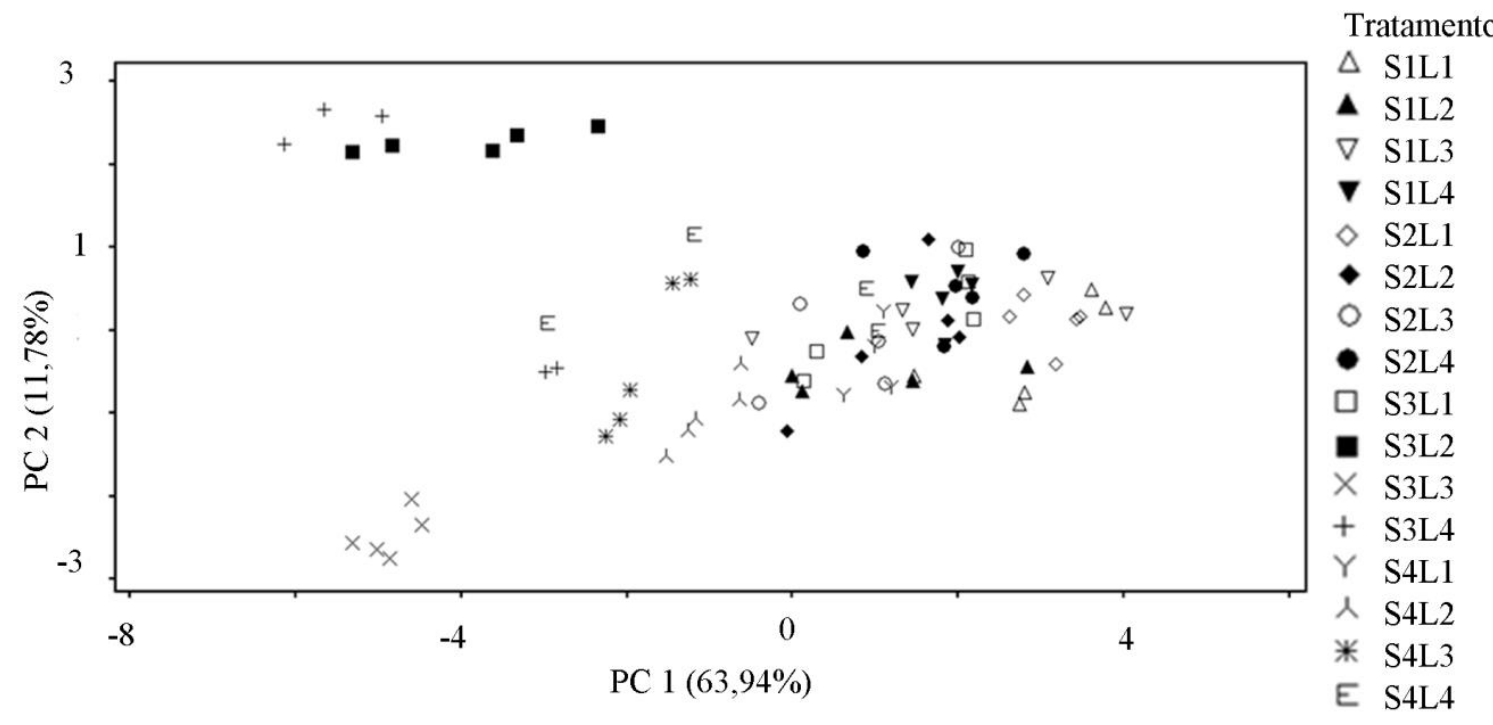

Figure 2. Principal components analysis and the scores obtained from PC1 X PC2.

Figura 2. Análise dos componentes principais e os escores obtidos de PC1 X PC2.

In this study, it was observed that $S$. terebinthifolius seedlings produced with seeds from S4, site with the higher altitude $(1,048.7 \mathrm{~m})$, also presented an adequate development when subjected to 60,70 , and $100 \%$ luminosity (Figure 2), although having the higher percentage of non-germinated seeds in the germination test. Nevertheless, the seedlings that presented the lower development rates were those produced with S. terebinthifolius seeds from S1 (2,533 m altitude) and S2 (176.67 m altitude) subjected to a 50\% luminosity (S1L1 and S2L1, respectively). Besides the lower seedling production rates, it is worth mentioning that $S$. terebinthifolius seeds collected in $\mathrm{S} 1$ obtained the better results in the germination test.

Nevertheless, $S$. terebinthifolius seeds in general showed the capacity of being produced in different luminosity conditions (Figure 2). The values obtained for stem fresh mass + petiole (SFM), stem dry mass + petiole (SDM), root fresh mass (RFM), root dry mass (RDM), total fresh mass (TFM), and total dry mass (TDM) decreased as shading increased in all seed batches analyzed.

\section{DISCUSSION}

S. terebinthifolius mother plants used in this experiment were selected in four Atlantic Forest environments with different altitudes and environmental conditions. Thus, we considered intrinsic factors, characteristic of each species, and extrinsic, which can interfere in the germinative behavior, such as geographical origin and the seed collection season (SALOMÃO et al., 2003). There are no reports in the literature about the influence of the altitude of forest species on their seed's germination or on the vegetative development of their progeny.

Considering the lack of consensus about the better temperature for germination tests of S. terebinthifolius (SHIBATA et al., 2019), we used a photoperiod and alternated temperature of 30 and $25{ }^{\circ} \mathrm{C}$, which permitted the study of seeds' vigor. The factors evaluated were: first count of the germination, average period of germination, seedlings' length and dry mass. These factors permitted the observation that seeds from S1 (site with lower altitude) were more viable. Nevertheless, it is fundamental to consider seeds' quality, which directly interferes in seedlings' development, to obtain good quality forest plants' seedlings. Moreover, this study demonstrated that $S$. terebinthifolius seeds with better germination speed index, and higher rates of normal seedlings, root and aerial part length (São Francisco do Sul/SC, site with lower altitude) produced the seedlings with lower development rates in all luminosity levels. Santos et al. (2012) emphasize that seeds' physical and physiological characteristics may influence the process of seedlings emergence, survival and development in field conditions. However, little is known about the morphology and physiology of many forest species' seeds. Floriano (2004) states that approximately a third of the species germinate immediately under favorable conditions, and the others present varying levels of dormancy. During the germination process, when leaves emerge, the photosynthetic potential of the seedling increase, the absorption of nutrients from the environment starts, and the cotyledons have an abscission; hence, the plant starts producing their own nutrition (FLORIANO, 2004).

Thus, seeds with better germination results not always produce the better seedlings for field conditions. This fact is also partially related to the seedlings' management such as nutrition, irrigation, substrate, and container; 
factors that directly influence the seedling (SPADA et al., 2019). Thus, further studies about the technology of forest species' seeds are required, aiming to better comprehend aspects of germination and vigor, besides improving seedlings' initial evaluation, which would result in better propagation of the crop and success in its establishment (LAZAROTTO et al., 2013). Concerning plants used to recover degraded areas, it is fundamental to consider luminosity, temperature, and edaphic conditions; attributes that may affect the recolonization of populations (SILVA; MAIA, 2019). Therefore, the environment in which plants develop is a crucial factor for the production and growth of forest species' seedlings. It is necessary to comprehend how plants respond to abiotic factors such as light, temperature, water availability because these factors affect the establishment, development, and survival of seedlings.

In this sense, Oliveira \& Perez (2012), while studying Tabebuia aurea, verified that the species presented the capacity to grow in difference luminous intensities, although the plants developed better in environments with high luminosity levels. Our study had a similar result as $S$. terebinthifolius presented better vegetative development in high luminosity conditions. Nevertheless, it is worth mentioning that the response to the experiment proposed demonstrates the species adaptative capacity to luminous intensity variations. Consequently, the plant behaves as a pioneer in the ecological succession stage. Such results support the findings of Souza et al. (2013) and Neves et al. (2016) regarding the adaptative capacity of S. terebinthifolius to different environments. Nevertheless, Silva \& Maia (2019) verified that some pioneer species of the mangrove are not well-developed under full sunlight. The authors report that in deforestation conditions the human intervention is essential for regeneration, providing a $50 \%$ shading to obtain stability for seedlings. Therefore, it is fundamental to observe each species and biome's characteristics.

Thus, this study contributes to the knowledge of how S. terebinthifolius develops when subjected to different luminosity levels. This process permits the better comprehension of the interactions between plants and their environments, which may provide new theories about forest populations and communities' dynamics in the process of forest succession (TURCHETTO et al., 2015). Based on these results, good practices to produce highquality seedlings in a short period with maximal growth can be suggested, demonstrating the necessity of ideal conditions for the species with an adequate management (PINTO et al., 2016). Finally, the discrepancy found between the germination test and the vegetative development of $S$. terebinthifolius based on seed batches collected in sites with the same altitude reveals that the result might have been influenced by variables not considered in this study, such as seeds' genetic load. In this context, Silva et al. (2019) state that intrinsic genetic characteristics may difficult the obtention of forest species' seeds with maximal germination and vigor. Thus, accelerated aging and electrical conductivity tests are recommended to confirm seeds' vigor, identifying if the batch is viable and vigorous (SILVA et al, 2019).

\section{CONCLUSIONS}

- The S. terebinthifolius seeds collected in lower altitude $(2.5 \mathrm{~m})$ had higher viability, GSI, and performance in primary root length and aerial part of seedlings. However, they presented lower results for vegetative development when subjected to a $50 \%$ luminosity.

- $\quad$ The S. terebinthifolius seeds collected in an urban area with intermediate altitude (458 m) presented lower germination percentage and GSI, but better results for vegetative development at $70 \%$ luminosity.

- S. Terebinthifolius seedlings, when exposed to a luminosity higher than $60 \%$, presented better adaptation and development.

- Experiments about altitude and the influence of luminosity in seedlings' production are still in initial stage, requiring further studies to promote better development of S. terebinthifolius, in order to recover degraded areas, especially of the Atlantic Forest.

\section{ACKNOWLEDGEMENTS}

We would like to thank Itaipu Binacional, by providing access to the Laboratory of Seeds for the germination test and the nursery of the Refúgio Biológico Bela Vista to produce S. terebinthifolius seedlings. We also thank Veridiana Araújo Alves da Costa Pereira and Rodolfo Rubik for the experience exchange, which was fundamental for this research. 


\section{REFERENCIAS}

ALVARES, C. A.; STAPE, J. L.; SENTElhas, P. C.; GONÇALVES, J. L. M.; SPAROVEK, G. Köppen's climate classification map for Brazil. Meteorologische Zeitschrift, Stuttgart, v. 22, n. 6, p. 711-728, dez. 2013.

BRASIL. [Ministério da Agricultura, Pecuária e Abastecimento]. Regras para análise de sementes. Brasília: Secretaria de Defesa Agropecuária, Mapa/ACS, 2009, 399 p.

FLORIANO, E. P. Germinação e dormência de sementes florestais. Santa Rosa: Anorgs, 2004.

JACKSON, D. A. Stopping rules in principal components analysis: a comparison of heuristical and statistical approaches. Ecology, Toronto, v. 74, n.8, p. 2204 - 2214, 1993.

JOLLIFFE, I. T. Principal component analysis. New York: Springer, 2002.

LAZAROTTO, M.; MUNIZ, M. F. B.; BELTRAME, R.; SANTOS, A. F.; MEZZOMO, R.; PIVETA, G.; BLUME, E. Qualidade fisiológica e tratamentos de sementes de Cedrela fissilis procedentes do Sul do Brasil. Revista Árvore, Viçosa, v. 37, n. 2, p. 201-210, 2013.

MAEKAWA, L.; ALBUQUERQUE, M. C. F.; COELHO, M. F. B. Germinação de sementes de Aristolochia esperanzae O. Kuntze em diferentes temperaturas e condições de luminosidade. Revista Brasileira de Plantas Medicinais, Paulínia, v. 12, n. 1, p. 23-30, 2010.

MAGUIRE, J.D. Speeds of germination - aid in selection and evaluation for seedling emergence and vigor. Crop Science, Madison, v. 2, p. 176 - 177, 1962.

McCUNE, B.; MEFFORD, M.J. PC-ORD: Multivariate analysis of Ecological Data, Gleneden Beach: MjM Software Design, 1999.

MEDEIROS, A. C. S.; ZANON, A. Substratos e temperaturas para teste de germinação de sementes de aroeira-vermelha (Schinus terebinthifolius Raddi). Brasília: EMBRAPA, 1998. Comunicado Técnico n. 32.

NASSER, N. P. A.; RAMOS, R. F.; SCHEEREN, N. B.; DALLA NORA, D.; BELLÉ, C.; BETEMPS, D. L. Germinação de sementes de Bromelia antiacanthaem diferentes fotoperíodos. Revista Eletrônica Científica da UERGS, Porto Alegre, v. 5, n. 3, p. 296-301, 2019.

NEVES, E. J. M.; SANTOS, J. B. V. G.; RUAS, F. G.; VENTURA, J.A. Cultivo da aroeira-vermelha (Schinus terebinthifolius Raddi) para produção de pimenta-rosa. Colombo: Embrapa Florestas, 2016. Documento Técnico n. 294.

OLIVEIRA, A. K. M.; PEREZ, S. C. J. G. A. Crescimento inicial de Tabebuia aurea sob três intensidades luminosas. Ciência Florestal, Santa Maria, v. 22, n. 2, p. 263 - 273, 2012.

PINTO, J. R. S.; DOMBROSKI, J. L. D.; SANTOS JUNIOR, J. H.; SOUZA, G. O.; FREITAS, R. M. O. Growth of Mimosa caesalpiniifolia Benth., under shade in the northeast semi-arid region of Brazil. Revista Caatinga, Mossoró, v. 29, n. 2, p. 384-392, 2016.

RAMOS, M. G. C.; BERTO, T. S.; SILVA, L. G.; CRISÓSTOMO, N. M. S.; MELO, L. D. F. A.; MELO JUNIOR, J. L. A.; FARIAS, J. A. C.; FERREIRA, V. M. Efeito da luz e da temperatura na germinação de sementes de Mimosa bimucronata (DC) O. Kuntze. Revista Craibeiras de Agroecologia, Rio Largo, v. 5, n. 1, p. e9399, 2020.

SALOMÃO, A. N.; SOUSA-SILVA, J. C.; DAVIDE, A. C.; GONZÁLES, S.; TORRES, R. A. A.; WETZEL, M. M. V. S.; FIRETTI, F.; CALDAS, L. S. Germinação de sementes e produção de mudas de plantas do cerrado. (A. N. Salomão et al., ed.). Brasília: Rede de Sementes do Cerrado, 2003.

SANTOS, P. L.; FERREIRA, R. A.; ARAGÃO, A. G.; AMARAL, L. A.; OLIVEIRA, A. S. Estabelecimento de espécies florestais nativas por meio de semeadura direta para recuperação de áreas. Revista Árvore, Viçosa, v. 36, n. 2, p. 237-245, 2012.

SiBCS. Sistema Brasileiro de Classificação de Solos. Humberto Gonçalves dos Santos [et al.]. 5 ed., revista e ampliada - Brasília, DF: Embrapa, 2018.

SHIBATA, M.; CORREDOR-PRADO, J. P.; OLIVEIRA, L. M. Germinação e condutividade elétrica de sementes de Schinus terebinthifolius (Anacardiaceae). Acta Biológica Catarinense, Joinville, v. 6, n. 3, p. 98-105, 2019.

SILVA, J. N.; SILVA, M. A. D.; RODRIGUES, M. H. B. S.; ALVES, R. M. Testes de envelhecimento acelerado e condutividade elétrica para sementes de espécies florestais nativas: uma breve revisão. Meio Ambiente (Brasil), 
v. 1, n. 2, p. 24-30, 2019. Disponível em: https://meioambientebrasil.com.br/index.php/MABRA/article/view/30. Acesso em: 05 jan. 2020.

SILVA, M. M.; IRIGUCHI, E. K. K.; KASSUYA, C. A. L.; VIEIRA, M. C.; FOGLIO, M. A.; CARVALHO, J. E.; RUIZ, A. L. T. G.; SOUZA, K. P.; FORMAGIO, A. S. N. Schinus terebinthifolius: phenolic constituents and in vitro antioxidant, antiproliferative and in vivo anti-inflammatory activities. Brazilian Journal of Pharmacognosy, Curitiba, v. 27, p. 445-452, 2017.

SILVA, N. R.; MAIA, R. C. Evaluation of the growth and survival of mangrove seedlings under different light intensities: simulating the effect of mangrove deforestation. Revista Árvore, Viçosa, v.43, n. 3, p. 1-11, 2019.

SOUZA, D. C. L.; SILVA-MANN, R.; FERREIRA, R. A; GOMES, L. J.; ALMEIDA, T. S.; OLIVEIRA, A. S.; PEREIRA, G. S.; GOIS, I. B. Produção de frutos e características morfofisiológicas de Schinus terebinthifolius Raddi., na região do baixo São Francisco. Revista Árvore, Viçosa, v. 37, n. 5, p. 923 - 932, 2013.

SPADA, G.; UESUGI, G.; SILVA, R. B.; SILVA, M. R. Qualidade de mudas de Pau d'alho sob diferentes doses e frequências de aplicação de nutrientes. Colloquium Agrariae, Presidente Prudente, v. 15, n.2, p. 121-132, 2019.

TURCHETTO, F.; TABALDI, L. A.; RORATO, D. G.; GOMES, D. R. Aspectos eco-fisiológicos limitantes da regeneração natural. Ecologia e Nutrição Florestal, Santa Maria, v. 3, n. 1, p. 18-30, 2015. 